\title{
Using Mobile Apps to Support Effective Game-Based Learning in the Mathematics Classroom
}

\author{
Wen-Hung Chao, Ching-Yu Yang, Sheng-Min Hsien, and Rong-Chi Chang
}

\begin{abstract}
Math is considered as the basis of the development of science, technology and thought. Traditional teaching methods emphasize on repeatedly exercising Math problems, which lead to a result that students lack understanding and thinking. Theming on elementary Math "Graphics and Space," this study has developed an interactive Math learning material (APP) through the ADDIE teaching design model. The content of this App contains units of Math "Volume", "Surface Area", "Bulk", "Area", "Perimeter." Each unit has corresponding test questions. Through the experimental design, this study understands the learning outcomes before and after school children have applied digital learning materials and further confers the differences between high-accomplished school children and ordinary children by way of digital learning materials. The experimental result indicates that the digital learning materials App designed by the institute has enhanced the interests of school children to learn Math. The grades before and after the test indicate the students' grades have significantly improved after applying the digital learning materials App. Besides, the digital learning materials App have significant help to the low-accomplished school children.
\end{abstract}

Index Terms - Game-based learning, mobile app, digital learning, mathematics.

\section{INTRODUCTION}

Mathematics is recognized as the foundation of science, technology and intellectual development and is also an index of civilization evolution. Traditional Math teaching interprets logic training by forcedly memorizing formulas and definition composed by abstract symbols. Cramming way of learning has led to a result that students lack of interest in learning Math. A research indicates that students who have more confidence in learning Math have better performance in their Math achievement. Children generally understand the importance of Math, however, they still have a sense of fear about Math. If children's curiosity about Math can be arisen and they are also willing to learn, their Math basis can then be established. Such a result shall lead to a good one in science or thought development in the future.

The Ministry of Education Grade 1-9 Curriculum Guidelines [1] have attached much important to Math

Manuscript received April 30, 2017; revised September 1, 2017. This work was supported in part by the Ministry of Science and Technology of the Republic of China under contract 102-2511-S-468-005-MY2.

Wen-Hung Chao and Ching-Yu Yang are with the Department of Creative Product and Game Design, Chienkuo Technology University and the Creative Design, Asia University, Taiwan, R.O.C.

Sheng-Min Hsien is with the College of Creative Design, Asia University, Taichung, 413, Taiwan, R.O.C.

Rong-Chi Chang is with the Taiwan Police College, Taipei, 106, Taiwan, R.O.C. (e-mail: roger@mail.tpa.edu.tw). curriculum for elementary school students. Math Learning includes four topics including 'Number and Quantity', 'Shape and Space', 'Probability and Statistics', and 'Algebra' so as to have children be cultivated with abilities of question-solving and expect that children are capable to effectively apply knowledge of Math to solving practical problems in their lives.

With the development of digital technology, teaching has been integrated with more software and hardware equipments to make teaching more lively and diversified. Educators often apply attractive features of games to help learners to learn. Prensky [2] believed that game-based learning method was to integrate the content of learning with the frame of games and apply the feature of digital games to arise learners' motivation so that learners could concentrate themselves on learning in games to enjoy themselves and further achieve the goal of learning.

The study has designed a game-based Math learning APP through digital technology. This digital game provides with interactive mode and appropriate learning system. Such content of Math game contains challenges which can promote learners to think and increase their learn effects.

\section{LITERATURE REVIEW}

Digital game-based learning [3] is regarded as the most promising technological supplementary teaching method. Digital games create situational learning environment, wherein students are able to learn various kinds of knowledge through playing games and further apply the knowledge they have learned to real situations. [4]. While playing games, students need a higher level of thinking including the use of strategies, hypotheses verification and problem-solving rather than memorizing or simply understanding [5]. Cagiltay [6] mentioned that in comparison with traditional teaching methods, digital game-based learning can provide students with a more interesting environment to learn. The result of research indicates that games are really loved by the students and also make learning more interesting.

Volume is a measurement of 3D space, the concept of 3D space, and is also a part of geometry. Wheately [7] found in his study that spatial ability and visual heart was like thinking in Math and played a very important role in learning. There is a link between spatial ability and Math learning, having profound importance in learning Math. And Bishop [8] thought that the images generated by computer had functions of incentives and strengthening on students' visualization development. It is a useful tool in the development of students' visualization.

Bishop [9] suggested that spatial ability could be gained 
first by physical operation or computer's operation and then internalized into mind images operation. Physical operation helps students to have initial learning and understanding about concept of space. By operating computers, students are able to carry out spatial concept and verifying learning results. And mind images operation helps to gain space capabilities. Therefore, computers can be said to be an important supplementary tool in learning geometry. Thus, Clements and Battista [10] suggested that when learning geometry, appropriate computer software could be adopted. Taking the above-mentioned in volume teaching, students can begin to learn from the simple and regular object volume. The images generated by computers and computers operation help to arise students' interest and motivation and further promote their learning in volume concept and spatial concept so as to enhance students' ability in spatial concept.

Therefore, the study has aimed at $5^{\text {th }}$-grade elementary students to design an interactive digital learning material (APP). The purpose is to arise students' self-learning motivation, and further assist Math learning unit of ' $3 \mathrm{D}$ ' and 'Space.' By way of interactive operation, students are able to understand the responding relationship between the cube and the develop diagram. In the process of experimental design, the study has researched and discussed the learning achieving difference traditional Math learning method and interactive digital materials.

\section{RESEARCH METHODS}

\section{A. Game-Based Learning Environment}

The Institute has designed an interactive digital learning APP, which guides children to enter to play game levels in game maps. There are five levels in the game including, Perimeter, Area, Surface Area, Volume and Capacity. There are 10 learning programs in each unit. Children are able to learn Math knowledge and principles by interactive operation For example, children can observe actual number of area in Rotation 3D picture. By viewing the animation of a develop diagram, children are able to understand how surfaces are composed and how it displays after the diagram is developed. In the process of learning, this interactive APP also provides immediate tests. Children can answer the questions by following the instructions of the questions to have their learning verified. While learning, children can operate APP on their own without the guidance of teachers so that children are able to study themselves and to think how to pass the game levels to get the scores. As shown on Figure 1, it displays effects of interactive learning media.

\section{B. Participants and Design}

In order to understand how effectively this system can assist children to learn Math, the study has applied Quasi-experimental Design. This experiment aims at three classes of 5th-grade elementary students in Taiwan with a total number of 64 students. 34 of them are male students and 30 are female ones.

In this study, the experiment is carried on in a way that students 'learn on their own.' Every child has a basic concept of '3D developed diagram,' which is also called 'prepared knowledge.' Four of the children are in a team to operate "Interactive Math Learning APP developed by the study on Apple iPad. Learning units contain 'Surface Area', 'Volume' and 'Area' and so on. The experiment was carried on for three weeks and each time it was carried on for 45 minutes every week. On the third week, a test and questionnaire after learning were taken. In the end, a sampled interview was carried on between the teachers and children.

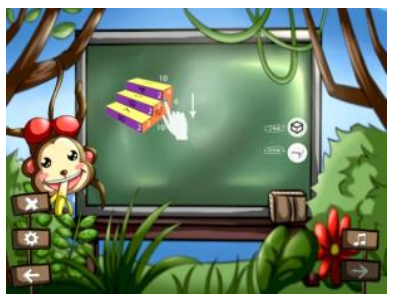

(a) To operate interactively with fingers

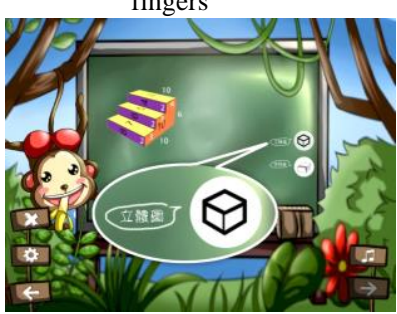

(c) To display 3D effect of object by $3 \mathrm{D}$ tools

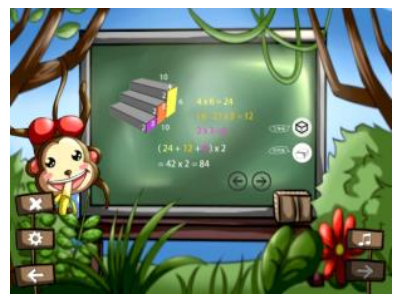

(b) Picture of question-solving process

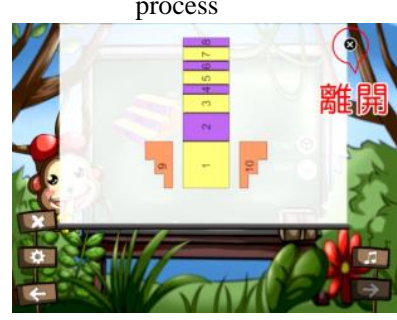

(d) Examples of 3D object developed diagram
Fig. 1. Display way of interactive learning.

\section{EXPERIMENT}

\section{A. Analysis of Learning Effectiveness}

The test aims at elementary school's $5^{\text {th }}$-grade students of a total number of 64. Every student taking the test is equipped with basic Math knowledge of "a develop diagram of a square". Digital learning materials are introduced in this experiment so that the students are able to learn a unit called "Surface Area" by way of "self-study". The study makes a comparative analysis of performance difference by applying the Math scores of an exam as a pre-test to be compared with the surface area test.

According to the experimental statistics, the average score of pre-test is 81.69 and after applying digital learning materials, the average score of the post-test is 85.59 , which shows an increase of 3.9. The overall scores of the students have a significant progress, and the learning outcomes also vary (as Table I).

TABLE I: PERFORMANCE DIFFERENCE ANALYSIS OF TEST SCORES BEFORE AND AFTER THE TEST

\begin{tabular}{c|c|c|c}
\hline & No. & Average & $\begin{array}{c}\text { Standard } \\
\text { Deviation }\end{array}$ \\
\hline Exam scores (pre-test) & 64 & 81.69 & 17.075 \\
Surface area test (post-test) & 64 & 85.59 & 17.476 \\
\hline
\end{tabular}

To analyze with learning process of both male and female children, the pre-test average score of the male children is 80.38 and the post-test average score is 83.71 , which shows an improvement of 3.33 points. The pre-test average score of the female children is 84.33 and the post-test average score is 87.79 , which shows an improvement of 3.46 points. In this 
study, scores of both male and female children who apply interactive Math learning materials are improved while the female children have slightly more improvement than the male children, as shown in Table II.

TABLE II: SEX SCORE DIFFERENCE OF INTERACTIVE DIGITAL LEARNING

\begin{tabular}{cc|c|c|c|c}
\hline & Sex & No. & Average & $\begin{array}{c}\text { Standard } \\
\text { Deviation }\end{array}$ & $\begin{array}{c}\text { Standard error of } \\
\text { Average }\end{array}$ \\
\hline \multirow{2}{*}{$\begin{array}{c}\text { Exam } \\
\text { Scores }\end{array}$} & Male & 34 & 80.38 & 18.112 & 3.106 \\
\cline { 2 - 6 } Female & 30 & 84.33 & 14.812 & 2.704 \\
\hline \multirow{2}{*}{$\begin{array}{c}\text { Surface } \\
\text { area test }\end{array}$} & Male & 34 & 83.71 & 18.543 & 3.180 \\
\cline { 2 - 6 } & Female & 30 & 87.79 & 16.176 & 3.004 \\
\hline
\end{tabular}

In the objects of the study, we call those whose Math levels are excellent high-achieving students. In order to understand if there is any performance difference after the high-achieving students have applied interactive digital learning materials, we implement an experiment before and after learning.

The pre-test score of the high achieving students is 95.86 and post-test score is to 96.71 with an increase of 0.85 . High-achieving students' Math scores have already led common students' score. After this experiment of their applying digital learning materials, high-achieving students have made progress, but there is little change in the results. The common students' pre-test score is 70.28 and after applying the digital materials, post-test score is 76.69 with an increase of 6.41. It was found from the experiment though the common students' scores are not as good as high-achieving students', their rate of progress is higher than the high-achieving students'. There is an obvious difference between the two (as Table III).

After applying Analysis of Variance (ANOVA), the group comparative value between the pre-test and post-test is $\mathrm{P}$ $<0.05$, which has reached a significant level and this indicates there is a significant difference when high achieving students and common students have applied the interactive digital learning materials. It can be seen that the digital learning materials do help to improve the leaning achievements of both the high-achieving and common students (as Table IV).

\section{B. Analysis of the Questionnaire}

Through "Technology Acceptance Mode" Scale has divided the questions into three main facets to implement analysis of learning effectiveness and the questionnaire is as follows Table V. It can be learned from the statistics, the design of interactive digital learning materials of the experiment, in all, is recognized by every child who also thinks it is interesting and it can help him learn Math without any fear and it is accepted by the elementary school students.

In the aspect of learning interest: $83.6 \%$ of students believe this interactive learning material is more attractive than the text books. As to its usability, the students think that "3D Rotation" function (85.1\%) and "Develop Diagram" function $(86.6 \%)$ are easy to operate.

However, in Q7, 7.5\% children think some interactive portions are not easy to operate and it is difficult to understand the 3D structure. While confronting situation like this, the teacher can guide the children one-to-one to help them learn smoothly. In the aspect of availability, most children can accept digital learning materials as a supplement during the class. However, the survey value of "learning interest" and "usability" are relatively low.

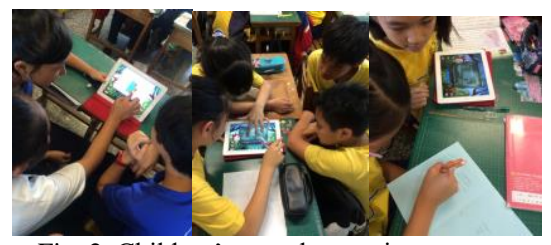

Fig. 2. Children's actual operation process.

\section{CONCLUSION}

Since the concept of education nowadays has kept change, we expect our children have a diversified environment to study. In recent years, with advance and popularization of science technology, digital learning materials have been gradually introduced to the environments. Different modes of digital learning by applying digital tools, computer equipment or mobile devices are provided for the students to study. Smart campus and digital learning shall become learning mode in the classroom in the future and mobile APP diversification and convenience shall become an option of mobile learning. Therefore, to develop learning materials and APP modes suitable for students will be a possible direction to be developed in the education market.

According to the experimental and the results of the study, we have concluded as follows:

1) The academic performances of high-achieving and common children who apply interactive digital learning

After the children whose Math level is more excellent have applied the interactive digital learning materials, through the test, their scores are still very high. Although these children have made progress, the growing space is small. Thus, high-achieving children who apply digital learning materials will not get worse scores. As to those common children except high-achieving children and those children whose Math scores are lower, after learning by applying digital learning materials, their scores are still not as good as high-achieving children, but the overall rate of their progress is very big. From this, digital learning does help the children a lot in learning.

2) The learning attitude of the children after applying interactive digital learning materials

According to the questionnaire, most children can accept interactive digital learning materials and they believe such learning method can help to increase their interests in learning Math and also help them understand the unit of surface area as well to enhance the effectiveness of learning. In addition, the children believe that the content of interactive digital learning material is interesting. Most children love the virtual character in the materials very much and show their positive and aggressive attitudes while learning.

TABLE III: STATISTICS OF MATH SCORES BETWEEN HIGH-ACHIEVING AND COMMON STUDENTS

\begin{tabular}{cc|c|c|c|c}
\hline & Achievement & No. & Average & $\begin{array}{c}\text { Standard } \\
\text { Deviation }\end{array}$ & $\begin{array}{c}\text { Standard error } \\
\text { of Average }\end{array}$ \\
\hline \multirow{2}{*}{ Exam Scores } & High-achieving & 29 & 95.86 & 3.136 & .582 \\
\hline $\begin{array}{c}\text { Surface Area } \\
\text { Test }\end{array}$ & 35 & 70.28 & 14.996 & 2.499 \\
\cline { 2 - 6 } & High-achieving & 29 & 96.71 & 5.098 & .963 \\
\hline
\end{tabular}




\begin{tabular}{|c|c|c|c|c|c|c|}
\hline \multicolumn{3}{|c|}{ students } & & & & \\
\hline \multicolumn{7}{|c|}{$\begin{array}{l}\text { TABLE IV: ANALYSIS OF VARIANCE BETWEEN HIGH-ACHIEVING AND } \\
\text { COMMON STUDENTS }\end{array}$} \\
\hline & & $\begin{array}{l}\text { Sum of } \\
\text { Square }\end{array}$ & DOF & $\begin{array}{c}\text { Average Sum } \\
\text { of Square }\end{array}$ & $\mathrm{F}$ & Significance \\
\hline \multirow{3}{*}{$\begin{array}{l}\text { Exam } \\
\text { scores }\end{array}$} & $\begin{array}{c}\text { between } \\
\text { group }\end{array}$ & 10513.176 & 1 & 10513.176 & 81.301 & .000 \\
\hline & in group & 8146.670 & 63 & 129.312 & & \\
\hline & Total & 18659.846 & 64 & & & \\
\hline \multirow{3}{*}{$\begin{array}{c}\text { Surface } \\
\text { Area } \\
\text { Test }\end{array}$} & $\begin{array}{c}\text { between } \\
\text { group }\end{array}$ & 6240.013 & 1 & \multirow{3}{*}{$\begin{array}{l}6240.013 \\
208.119\end{array}$} & 29.983 & \multirow[t]{3}{*}{.000} \\
\hline & In group & 12695.257 & 61 & & & \\
\hline & Total & 18935.270 & 62 & & & \\
\hline
\end{tabular}

$* p<.05 . * * p<.01 . * * * p<.001$.

TABLE V: INTERACTIVE MATH LEARNING APP ACCEPTANCE QUESTIONNAIRE ANALYSIS (\%)

\begin{tabular}{|c|c|c|c|c|c|c|}
\hline \multirow[b]{2}{*}{$\begin{array}{l}\text { Question } \\
\text { Aspect }\end{array}$} & \multirow[b]{2}{*}{ uestions } & \multicolumn{5}{|c|}{ Statistics (\%) } \\
\hline & & $\begin{array}{c}\text { very } \\
\text { much } \\
\text { disagree }\end{array}$ & disagree & $\begin{array}{c}\text { No } \\
\text { comment }\end{array}$ & agree & $\begin{array}{l}\text { very } \\
\text { much } \\
\text { agree }\end{array}$ \\
\hline \multirow{3}{*}{$\begin{array}{c}\text { Learning } \\
\text { Interest }\end{array}$} & \begin{tabular}{|} 
Q1 It is more \\
interesting to learn by \\
applying interactive \\
learning materials \\
than textbooks.
\end{tabular} & 0 & 1.5 & 9.0 & 22.4 & 61.2 \\
\hline & \begin{tabular}{|c|} 
Q2 By applying \\
interactive learning \\
materials, it helps me \\
increase my learning \\
motivation
\end{tabular} & 0 & 0 & 14.9 & 35.8 & 43.3 \\
\hline & $\begin{array}{c}\text { Q3 Appling } \\
\text { interactive digital } \\
\text { learning materials, } \\
\text { makes me more } \\
\text { interested in Math. }\end{array}$ & 0 & 3.0 & 16.4 & 32.8 & 41.8 \\
\hline \multirow{4}{*}{ Usability } & \begin{tabular}{|c|} 
Q4 The interactive \\
way in 'Learning \\
Fun' questions is easy \\
to be used.
\end{tabular} & 0 & 1.5 & 16.4 & 31.3 & 44.8 \\
\hline & $\begin{array}{l}\text { Q5 "3D rotation" } \\
\text { function helps me to } \\
\text { understand the } \\
\text { structure of the } \\
\text { surface. }\end{array}$ & 1.5 & 0 & 7.5 & 19.4 & 65.7 \\
\hline & $\begin{array}{c}\text { Q6 "Develop } \\
\text { Diagram" function in } \\
\text { learning interest helps } \\
\text { me understand the } \\
\text { combination of } \\
\text { surface. } \\
\end{array}$ & 0 & 0 & 7.5 & 22.4 & 64.2 \\
\hline & $\begin{array}{c}\text { Q7 In questions of } \\
\text { learning interest, 3D } \\
\text { display is easy to } \\
\text { operate. }\end{array}$ & 0 & 7.5 & 7.5 & 32.8 & 46.3 \\
\hline \multirow{4}{*}{ Availability } & \begin{tabular}{|c|} 
Q8 Question-solving \\
process in learning \\
interest is helpful in \\
learning Math. \\
\end{tabular} & 0 & 0 & 13.4 & 31.3 & 47.8 \\
\hline & \begin{tabular}{|c|} 
Q9 “Challenge" \\
questions are \\
diversified and can \\
increase chances for \\
me to practice. \\
\end{tabular} & 0 & 0 & 14.9 & 23.9 & 53.7 \\
\hline & $\begin{array}{l}\text { Q10 I hope } \\
\text { interactive learning } \\
\text { materials can be } \\
\text { added in Math } \\
\text { learning in classes. }\end{array}$ & 1.5 & 4.5 & 7.5 & 23.9 & 55.2 \\
\hline & Q11 I hope other & 0 & 1.5 & 16.4 & 31.3 & 43.3 \\
\hline
\end{tabular}

\begin{tabular}{c|c|c|c|c|c|c}
\hline \multirow{3}{*}{$\begin{array}{c}\text { Question } \\
\text { Aspect }\end{array}$} & uestions & $\begin{array}{c}\text { very } \\
\text { much } \\
\text { disagree }\end{array}$ & disagree & $\begin{array}{c}\text { No } \\
\text { comment }\end{array}$ & agree & $\begin{array}{c}\text { very } \\
\text { much } \\
\text { agree }\end{array}$ \\
\cline { 2 - 6 } & $\begin{array}{c}\text { Math units can be } \\
\text { developed too }\end{array}$ & & & & & \\
\hline
\end{tabular}

\section{ACKNOWLEDGMENTS}

This work was supported in part by the Ministry of Science and Technology of the Republic of China under contract 102-2511-S-468-005-MY2.

\section{REFERENCES}

[1] Ministry of Education, General Guidelines of Grade 1-9 Curriculum of Elementary and Junior High School Education, 2003.

[2] M. Prensky, "Digital natives, digital immigrants part 1," On the Horizon, vol. 9, no. 5, 2001, pp. 1-6.

[3] R. Eck, "Digital game-based learning: It's not just the digital natives who are restless," EDUCAUSE Review, vol. 41, no. 2, 2006, pp.16-30.

[4] M. J. Dondlinger, "Educational video game design: A review of the literature," Journal of Applied Educational Technology, vol. 4, no. 1, 2007, pp.21-31.

[5] M. Prensky, Digital Game-Based Learning, McGraw-Hill, 2004.

[6] N. Cagiltay and G. Gökdal, "What do computer games promise for engineering students," in Proc. EdMedia: World Conference on Educational Media and Technology, 2001, pp. 3912-3917.

[7] G. H. Wheatley, "Spatial sense and mathematics learning," Arithmetic Teacher, 1990, vol. 37, no. 6, pp.10-11.

[8] A. J. Bishop, "Review of research on visualization in mathematics education." Focus on Learning Problems in Mathematics, vol. 11, no. 1, 1989, pp.7-16

[9] A. J. Bishop, "Review of "How Chinese learn mathematics Perspectives from insiders," Journal of Mathematics Education, vol. 14, no. 2, 2005, pp. 100-102.

[10] D. H. Clements and M. T. Battista, "Geometry and spatial reasoning," Handbook of Research on Mathematics Teaching and Learning, 1992, pp. 420-464. New York: MacMillan.

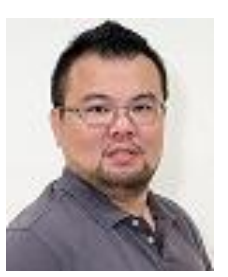

Wen-Hung Chao is an assistant professor of creative product and game design at Chienkuo Technology University and also works as the manager of product in the Appedu Compute Design Institute, Taiwan. He specializes in game design and digital design. His research focuses on multimedia computing, interactive media design, augmented reality and virtual reality.

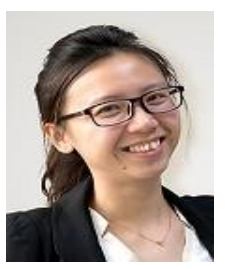

Ching-Yu Yang is a lecturer of creative product and game design at Chienkuo Technology University and also works as the design director in the sensation design, Taiwan. She specializes in commercial design and product design. Her research focuses on user interface design, package design, cultural product design and interactive media design.

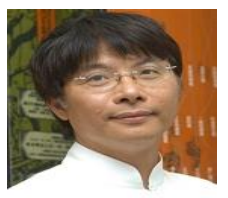

Sheng-Min Hsieh is a professor of visual communication design at Asia University and also works as the consultant in the many design community, Taiwan. He specializes in visual communication design. His research focuses on visual psychology, illustration design, art history and communication design.

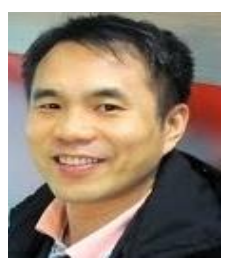

Rong-Chi Chang is an associate professor of technology crime investigation at Taiwan Police College and also works as the program coordinator of applied computer science in the multimedia computing laboratory, Taiwan. He specializes in digital design and application. His research focuses on multimedia computing, interactive media design, computer vision, and interactive technologies. 